\title{
Axillary Bud Proliferation Approach for Plant Biodiversity Conservation and Restoration
}

\author{
F. Ngezahayo ${ }^{1}$ and B. Liu ${ }^{2}$ \\ ${ }^{1}$ Section Biologie-Chimie, Département des Sciences Naturelles, École Normale Supérieure, BP 6983, Bujumbura, Burundi \\ ${ }^{2}$ Key Laboratory of Molecular Epigenetics of the Ministry of Education (MOE), Northeast Normal University, \\ Changchun 130024, China \\ Correspondence should be addressed to F. Ngezahayo; ngezafre@yahoo.fr
}

Received 16 January 2014; Accepted 8 March 2014; Published 6 April 2014

Academic Editor: Rafael Riosmena-Rodríguez

Copyright (C) 2014 F. Ngezahayo and B. Liu. This is an open access article distributed under the Creative Commons Attribution License, which permits unrestricted use, distribution, and reproduction in any medium, provided the original work is properly cited.

Due to mainly human population pressure and activities, global biodiversity is getting reduced and particularly plant biodiversity is becoming at high risk of extinction. Consequently, many efforts have been deployed to develop conservation methods. Because it does not involve cell dedifferentiation of differentiated cells but rather the development and growth of new shoots from preexisting meristems, the axillary bud proliferation approach is the method offering least risk of genetic instability. Indeed, meristems are more resistant to genetic changes than disorganized tissues. The present review explored through the scientific literature the axillary bud proliferation approach and the possible somaclonal variation that could arise from it. Almost genetic stability or low level of genetic variation is often reported. On the contrary, in a few cases studied to date, DNA methylation alterations often appeared in the progenies, showing epigenetic variations in the regenerated plants from axillary bud culture. Fortunately, epigenetic changes are often temporary and plants may revert to the normal phenotype. Thus, in the absence of genetic variations and the existence of reverting epigenetic changes over time, axillary bud culture can be adopted as an alternative nonconventional way of conserving and restoring of plant biodiversity.

\section{Introduction}

Global biodiversity is defined as the variation of all life on earth and the ecological complexes in which it occurs [1]. Biodiversity refers to genetic diversity, species diversity, and ecosystem diversity $[2,3]$ and includes the forest and agricultural ecosystems and the wild animals [4].

Among the above components, plants represent a vital part of biodiversity and healthy ecosystems. They provide multiple ecosystem services including production of oxygen for the rest of living organisms $[5,6]$, removal of atmospheric carbon dioxide emissions in the photosynthesis process, creation and stabilization of soil, protection of watersheds, and provision of natural resources including food, fibre, fuel, shelter, and medicine [7]. They also play an important role in the water cycle and constitute habitat for a wide range of other living organisms. Thus, plants are the basis for life on earth and humans are quite dependent on them [8-10] given that they are fundamental structural and nutrient-sequestering components of most ecosystems.

Due to dependency on biodiversity, the number of threatened plant species has gradually increased during the last decade, the maximum being observed in 2011 [11].

The key factor in threats to earth's biodiversity is often cited as the human population size, density, and growth [1215]. As reported by the United Nations Population Division, the world had 2.5 billion people in 1950 . This number was almost tripled in 2005 by reaching 6.5 billion people, while it is projected to rise to more than 9 billion people by 2050 [16]. The less developed world is showed to have the highest rate of human population growth [17]. Thus, the needs for this growing population must have much impact on biodiversity on which it depends for its survival.

The world's human population exponential growth and spatial expansion have been accompanied by changes in landuse, pollution, and overexploitation of natural resources [18], 
which in turn engender loss of species [19] and endangerment of ecosystem functioning [20-35] in three main ways.

First, human-driven land-use is among the greatest threats to terrestrial and aquatic biodiversity $[36,37]$ by causing habitat destruction in protected and nonprotected areas, which is motivated mostly by agricultural expansion [38-41].

Second, urbanization, another consequence of human population massive growth, is considered to be another major threat to biodiversity by a wide range of scientific literature [38, 42-53]. For instance, due to human population growth and migration, there will be nearly 2 billion new urban residents by 2030 [54], which means further habitat destruction accompanied by various sorts of pollution.

Third and corollary to the above impacts, human pressure is also responsible for different types of pollution, leading mainly to climate change, such as global warming [55]. The main consequences of climate change or global warming are (i) the extinction of plant pollinators $[56,57]$ which causes loss of genetic diversity and (ii) the habitat fragmentation resulting in loss of genetic diversity in local and global plant populations and bottleneck events in these populations [58]

These anthropogenic activities place global biodiversity and particularly plant species at risk of extinction even in the biodiversity hotspots $[59,60]$.

In order to reduce the growing extinction risk of plant biodiversity, its conservation and restoration was revealed to be more than a priority. Two conventional methods of conservation are used, in situ and ex situ conservation, which are complementary to each other. In situ methods allow conservation to occur with ongoing natural evolutionary processes $[61,62]$. Ex situ strategies maintain the biological materials outside their natural habitats [63] and often use plant biotechnology such as plant cryopreservation or micropropagation. The most important technique in micropropagation is meristem proliferation in which apical buds or nodal segments harbouring an axillary bud are cultured to regenerate multiple shoots without intervention of callus phase [64]. Meristem culture is also an efficient tool for regeneration, elimination of viruses from infected plants, and then production of virus-free seed material of different plant species [65-67].

In the present review, we briefly present the axillary bud proliferation approach as an alternative way that can be used for plant biodiversity conservation and restoration.

\section{Axillary Bud Culture and Mass Propagation of Plant Species}

Among the methods developed for plant micropropagation, the axillary bud proliferation is the most used and is also considered the most suitable to guarantee genetic stability of the regenerated plants obtained. For rapid in vitro clonal propagation of plants, normally dormant axillary buds are induced to grow into multiple shoots by judicious use of growth regulators, cytokinins for activation and sprouting of dormant axillary bud and multiplication or cytokinin and auxin synergistic combinations for shoot multiplication.
In this way and because of its simplicity and reliability for clonal propagation, axillary bud culture was the method adopted for the mass micropropagation of various plants including almond [68], apple [69], Acacia mangium Willd [70], Cedrus [71], Eucalyptus [72], Anoectochilus formosanus Hayata [73], Swertia chirayita (Roxb. ex Fleming) H. Karst. [74], tea [75], Curcuma longa L. [76], Rosa rugosa Thunb. [77], hazelnut [78], marula tree [79], Fagopyrum dibotrys Hara mutant [80], Curcuma amada Roxb. [81], Alpinia galangal Linn [82], apple rootstock [83], apple rootstock Merton 793 [84], Cannabis sativa L. [85], hops [86], Allium ampeloprasum L. [87], squill [88], olive [89], Pinus thunbergii Parl. [90], Piper longum L. [91], Prosopis chilensis (Mol.) Stuntz [92], barley [93], rice [94], almond [95], Dendrobium longicornu Lindl. [96], and Mahonia leschenaultii Nutt. [97].

It is the stimulation of axillary buds to develop into a shoot [98] and this technique is comprised of the meristem and shoot tip culture and the bud culture [98]. It is a method exploiting the normal ontogenetic route for plant development by lateral meristems.

Since this technology does not involve cell dedifferentiation of differentiated cells but rather the development and growth of new shoots from preexisting meristems, it has been usually pointed out as the most faithful way of propagating plants in vitro. Indeed, it is thought to induce recovery of genetically stable and true-to-type progenies [99, 100], very little or no genetic variation [101], and epigenetic stability [102].

\section{Axillary Bud Culture and Somaclonal Variation}

Axillary bud culture is one of the multiple techniques of plant in vitro culture. A major problem associated with in vitro culture systems is the occurrence of somaclonal variation amongst subclones of one parental line $[103,104]$. Somaclonal variation is manifested as cytological abnormalities, frequent qualitative and quantitative phenotypic mutations, sequence change, gene activation and silencing $[105,106]$, and transposon and retrotransposon activation [107-110]. Thus, somaclonal variation is considered at both genetic and epigenetic levels.

Although somaclonal variation provides a valuable source of genetic variation for the improvement of crops through the selection of novel variants, which may show resistance to disease, improved quality, or higher yield [111114], it may result in off-types that reduce the commercial value of resultant plants [115] and then shall be an important obstacle for plant biodiversity conservation. Plant in vitro culture, being comprised of sequential dedifferentiation (formation of callus) and redifferentiation (regeneration into plants) stages [116, 117], represents traumatic stress to plant cells and organs and often engenders an array of genetic and epigenetic alterations [118].

It is generally assumed that axillary bud culture is the method offering least risk of genetic instability since meristems are more resistant to genetic changes than disorganized tissues $[119,120]$. Though it is sometimes species-specific 
TABLE 1: Clonally propagated plant species through axillary proliferation approach and the state of subsequent genetic somaclonal variation.

\begin{tabular}{|c|c|c|c|}
\hline Species & Used marker & Genetic variation & Reference \\
\hline Cedrus atlantica $\mathrm{L}$. & RAPD & Not significant & {$[71]$} \\
\hline Cedrus libani $\mathrm{L}$. & RAPD & Not significant & {$[71]$} \\
\hline Eucalyptus tereticornis Smith & RFLP, RAPD & No & {$[72]$} \\
\hline Eucalyptus camaldulensis Dehn. & RFLP, RAPD & No & {$[72]$} \\
\hline Anoectochilus formosanus $\mathrm{H}$. & ISSR & Low genetic instability & [73] \\
\hline Swertia chirayita (Roxb. ex Fleming) H. Karst. & ISSR & No & {$[74]$} \\
\hline Curcuma longa $L$. & Cytophotometry and RAPD & No & {$[76]$} \\
\hline Prunus dulcis [Mill.] D. A. Webb & RAPD and ISSR & No & {$[95]$} \\
\hline Alpinia galanga $\mathrm{L}$. & RAPD and ISSR & No & {$[82]$} \\
\hline Malus pumila Mill. & RAPD & Not significant & {$[83]$} \\
\hline Apple rootstock Merton 1973 & ISSR & No & {$[84]$} \\
\hline Cannabis sativa $\mathrm{L}$. & ISSR & No & {$[85]$} \\
\hline Humulus lupulus L. & RAPD and REMAP & No & {$[86]$} \\
\hline Allium ampeloprasum $L$. & ISSR & No & {$[87]$} \\
\hline Vitis spp. & RAPD and ISSR & No & [136] \\
\hline Hybrid hazelnut & RAPD & No & {$[78]$} \\
\hline Sclerocarya birrea subsp. caffra & RAPD & No & {$[79]$} \\
\hline Ochreinauclea missionis (Wall. ex G. Don) Ridsd. & ISSR & No & {$[108]$} \\
\hline Fragaria $x$ ananassa & RAPD-PCR & No & {$[137]$} \\
\hline $\begin{array}{l}\text { Doritaenopsis glenyle } \\
\text { "Labios" }\end{array}$ & RAPD & No & [127] \\
\hline Ocimum kilimandscharicum Guerke & RAPD & No & {$[138]$} \\
\hline
\end{tabular}

TABLE 2: Clonally propagated plant species through axillary proliferation approach and the state of subsequent epigenetic somaclonal variation.

\begin{tabular}{lccc}
\hline Species & Used marker & Epigenetic variation & Reference \\
\hline Bambusa balcooa Roxb. & MSAP & No & {$[121]$} \\
Cedrus atlantica L. and C. libani L. & HPLC & Yes & Yes \\
Corylus avellana L. & Isoschizomer restriction analysis & Yes & No \\
Malusxdomestica & MS-AFLP & Yes & {$[123]$} \\
Myrtus communis L. & HPLC & No & {$[122]$} \\
Pisum sativum L. & MSAP, HPCE & Yes & {$[125]$} \\
Solanum tuberosum L. & MS-AFLP & Yes & {$[126]$} \\
Vitis vinifera L. & MSAP & & Yes \\
Doritaenopsis glenyle & & & {$[127]$} \\
"Labios" & MSAP & & MSAP \\
\hline
\end{tabular}

$[71,75]$, genetic fidelity or no significant genetic variation is indeed often observed in the regenerants from axillary bud culture systems according to known scientific literature. In this concern, various DNA molecular markers were used such as cytophotometry, ISSR (intersimple sequence repeat), RAPD, RFLP (restriction fragment length polymorphism), and REMAP (retrotransposon microsatellite amplified polymorphism) markers and did not show genetic differences between regenerated progenies and their parental lines (Table 1).
Contrary to a wide range of genetic investigations in regenerated plants from axillary bud culture, there is no much work in the epigenetic way. Nonetheless, the axillary bud culture system may cause epigenetic alteration according to few papers regarding the epigenetic aspect of somaclonal variation (Table 2). On the investigated cases, epigenetic stability was only observed in three plants including Bambusa balcooa Roxb. [121], Myrtus communis L. [122], and Solanum tuberosum L. [102]. The remaining show DNA methylation alterations in Cedrus atlantica L. and C. libani L. [71], 


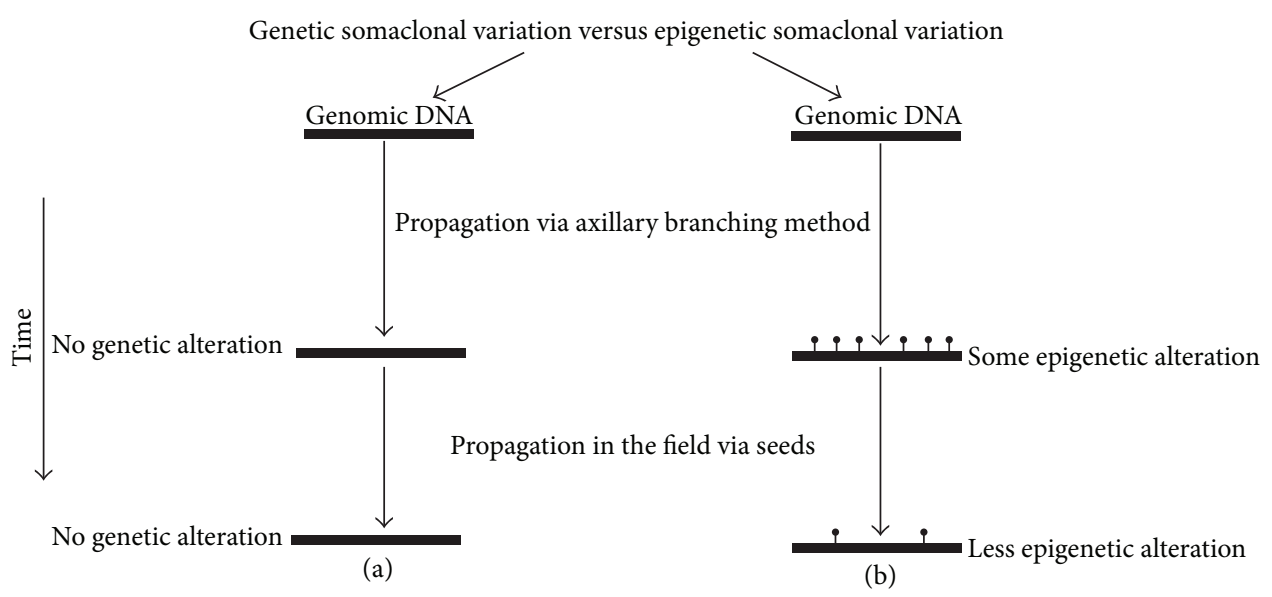

FIGURE 1: Schematic representation of the genetic (a) and epigenetic (b) variations arising from the axillary bud proliferation approach and their status over time, that is, after plant propagation in the field via the seeds (adapted from [135]).

Corylus avellana L. [123], Malusxdomestica cv. "Gala” [124], Pisum sativum L. [125], Vitis vinifera L. [126], Doritaenopsis glenyle "Labios" [127], and Humulus lupulus L. [86].

Interestingly in the same studied plant species, genetic variation is quite absent while epigenetic alterations occur $[86,127]$, showing that only epigenetics will impact on the phenotype of the progenies from axillary bud culture in such plants and will then alone govern the consequent variant phenotype.

\section{Axillary Bud Culture in Plant Biodiversity Conservation}

Biotechnology such as axillary bud culture is supposed to help in conservation and restoration of plants without affecting main features of the plants. It is known that phenotypic variations in living organisms are strongly governed by both genetic and epigenetic fluctuations [128-130]. Thus, conservation and restoration methods that could induce genetic and/or epigenetic variation such as somaclonal variations shall produce mutations in plant progenies which may affect their stability and viability.

By using axillary bud culture for mass propagation of various plant species and particularly the endangered ones, it is evident through the present review that genetic variations are almost absent (Table 1). This confirms a clonal fidelity and then true-to-type progenies. The genetic stability will then remain through propagation in the field via seeds of the genetically stable progenies (Figure 1(a)) unless genetic variability is induced by sexual and natural selection processes.

The genetic stability explored throughout this review was depicted only by one DNA molecular marker in some cases (Table 1). Nonetheless, the use of one type of molecular marker to assess the stability of in vitro propagated plants may be insufficient. This is why different authors have recently exploited more than one molecular marker for studying of somaclonal variation in regenerants of several plant species. For instance, a relatively low level of polymorphism was detected with RAPD markers in Actinidia deliciosa A. Chev. cultures, whereas the polymorphism was higher with SSR markers [131].

On the other hand, epigenetic changes are often observed even in the absence of genetic variation (Table 2). This may then produce off-to-types progenies at the epigenetic level. Epigenetics such as cytosine methylation has been proposed to have diverse cellular functions in eukaryotes, but its primary role was believed to serve as a genome surveillance and defense system such as taming of transposable elements $[132,133]$. This should then provoke their mobility throughout the genome and genetic mutations. Thus, assessment of epigenetic alterations arising from axillary bud culture process should be accompanied by the analysis of the possible consequent mobility of transposable elements.

Fortunately, epigenetic changes are often temporary and plants may revert to the normal phenotype relatively easily though some can be long-lasting and may even be transferred during sexual propagation $[134,135]$. By propagating the resulting progenies in the field via their seeds, there will be less epigenetic alteration in offspring (Figure 1(b)).

Thus, in the absence of genetic variations and the existence of reverting epigenetic changes over time, axillary bud culture can be adopted as an alternative way of conserving and restoring of endangered plant species. However, for a better planning of plant conservation and restoration by means of axillary bud proliferation approach, more than one genetic and epigenetic molecular marker should be used to rule out biased genetic and epigenetic results. This should be followed by the assessment of the status of transposable elements and the gene expression to assure the stability of the progenies.

\section{Conclusion}

The present review presented the benefits of the axillary bud culture as an alternative nonconventional way of conserving plant species which are facing extinction mainly due to human pressure. Evidence is increasing that axillary bud 
culture generates clonal fidelity and true-to-parental type progenies. It should however be synergistically used with other confirmed biotechnological methods of plant conservation such as cryopreservation in addition to conventional techniques. Moreover, close attention should be paid to the genetic and epigenetic variation as well as karyological and morphological stability brought by axillary bud proliferation approach before any conservation plan.

\section{Conflict of Interests}

The authors declare that there is no conflict of interests regarding the publication of this paper.

\section{Acknowledgment}

The authors thank General Director of Ecole Normale Supérieure for facilities provided.

\section{References}

[1] P. Leadley, H. M. Pereira, R. Alkemade et al., Biodiversity Scenarios: Projections of 21st Century Change in Biodiversity and Associated Ecosystem Services, Convention on Biological Diversity, Montreal, Canada, 2010.

[2] S. I. Dodson, T. F. H. Allen, S. R. Carpenter et al., Ecology, Oxford University Press, New York, NY, USA, 1998.

[3] K. J. Gaston and J. I. Spicer, Biodiversity: An Introduction, Blackwell Science, Oxford, UK, 1998.

[4] World Bank, "Ensuring the Future: The World Bank and Biodiversity, 1998-2004," Tech. Rep., World Bank, Environment Department, Washington, DC, USA.

[5] M. A. Huston, Biological Diversity: The Coexistence of Species on Changing Landscapes, Cambridge University Press, Cambridge, Mass, USA, 1994.

[6] R. B. Primack and R. T. Corlett, Tropical Rain Forests: An Ecological and Biogeographical Comparison, Blackwell Publishing, Oxford, UK, 2005.

[7] E. O. Wilson, The Diversity of Life, Penguin, London, UK, 1992.

[8] G. C. Daily, "Challenges in valuation," in Nature's Services: Societal Dependence on Natural ecosystems, G. C. Daily, Ed., pp. 365-374, Island Press, Washington, DC, USA, 1997.

[9] A. Balmford, A. Bruner, P. Cooper et al., "Ecology: economic reasons for conserving wild nature," Science, vol. 297, no. 5583, pp. 950-953, 2002.

[10] A. Hamilton and P. Hamilton, Plant Conservation: An Ecosystem Approach, Earthscan, London, UK, 2006.

[11] IUCN Red List version 2011.2, https://www.bolgermany.de/ dateien/How_many_species_IUCN_Data.pdf.

[12] G. L. Kirkland Jr. and R. S. Ostfeld, "Factors influencing variation among states in the number of federally listed mammals in the United States," Journal of Mammalogy, vol. 80, no. 3, pp. 711-719, 1999.

[13] K. Thompson and A. Jones, "Human population density and prediction of local plant extinction in Britain," Conservation Biology, vol. 13, no. 1, pp. 185-189, 1999.

[14] M. Cardillo, A. Purvis, W. Sechrest, J. L. Gittleman, J. Bielby, and G. M. Mace, "Human population density and extinction risk in the world's carnivores," PLoS Biology, vol. 2, no. 7, 2004.
[15] E. C. Ellis, E. C. Antill, and H. Kreft, "All is not loss: plant biodiversity in the anthropocene," PLoS ONE, vol. 7, no. 1, Article ID e30535, 2012.

[16] United Nations Population Division, World Population Prospects, 2008.

[17] United Nations Population Division, Briefing Packet, 1998 Revision of World Population Prospects, and World Population Prospects, the 2006 Revision.

[18] A. K. Diraiappah and S. Naeem, Millennium Ecosystem Assessment: Ecosystems and Human Well-Being: Biodiversity Synthesis, World Resources Institute, Washington, DC, USA, 2005.

[19] S. H. M. Butchart, M. Walpole, B. Collen et al., "Global biodiversity: indicators of recent declines," Science, vol. 328, no. 5982, pp. 1164-1168, 2010.

[20] F. S. Chapin III, E. S. Zavaleta, V. T. Eviner et al., "Consequences of changing biodiversity," Nature, vol. 405, no. 6783, pp. 234$242,2000$.

[21] M. Loreau, S. Naeem, P. Inchausti et al., "Ecology: biodiversity and ecosystem functioning: current knowledge and future challenges," Science, vol. 294, no. 5543, pp. 804-808, 2001.

[22] B. J. Cardinale, D. S. Srivastava, J. E. Duffy et al., "Effects of biodiversity on the functioning of trophic groups and ecosystems," Nature, vol. 443, no. 7114, pp. 989-992, 2006.

[23] D. U. Hooper, F. S. Chapin III, J. J. Ewel et al., "Effects of biodiversity on ecosystem functioning: a consensus of current knowledge," Ecological Monographs, vol. 75, no. 1, pp. 3-35, 2005.

[24] P. Balvanera, A. B. Pfisterer, N. Buchmann et al., "Quantifying the evidence for biodiversity effects on ecosystem functioning and services," Ecology Letters, vol. 9, no. 10, pp. 1146-1156, 2006.

[25] D. S. Srivastava and M. Vellend, "Biodiversity-ecosystem function research: is it relevant to conservation?" Annual Review of Ecology, Evolution, and Systematics, vol. 36, pp. 267-294, 2005.

[26] H. Hillebrand and B. Matthiessen, "Biodiversity in a complex world: consolidation and progress in functional biodiversity research," Ecology Letters, vol. 12, no. 12, pp. 1405-1419, 2009.

[27] J. Emmett Duffy, "Why biodiversity is important to the functioning of real-world ecosystems," Frontiers in Ecology and the Environment, vol. 7, no. 8, pp. 437-444, 2009.

[28] J. T. Kerr and D. J. Currie, "Effects of human activity on global extinction risk," Conservation Biology, vol. 9, no. 6, pp. 15281538,1995

[29] D. J. Forester and G. E. Machlis, "Modeling human factors that affect the loss of biodiversity," Conservation Biology, vol. 10, no. 4, pp. 1253-1263, 1996.

[30] K. Thompson and A. Jones, "Human population density and prediction of local plant extinction in Britain," Conservation Biology, vol. 13, no. 1, pp. 185-189, 1999.

[31] R. P. Cincotta, J. Wisnewski, and R. Engelman, "Human population in the biodiversity hotspots," Nature, vol. 404, no. 6781, pp. 990-992, 2000.

[32] M. L. McKinney, "Role of human population size in raising bird and mammal threat among nations," Animal Conservation, vol. 4, no. 1, pp. 45-57, 2001.

[33] A. H. Harcourt and S. A. Parks, "Threatened primates experience high human densities: adding an index of threat to the IUCN Red List criteria," Biological Conservation, vol. 109, no. 1, pp. 137-149, 2002.

[34] A. H. Harcourt, S. A. Parks, and R. Woodroffe, "Human density as an influence on species/area relationships: double jeopardy for small African reserves?" Biodiversity and Conservation, vol. 10, no. 6, pp. 1011-1026, 2001. 
[35] G. Ceballos and P. R. Ehrlich, "Mammal population losses and the extinction crisis," Science, vol. 296, no. 5569, pp. 904-907, 2002.

[36] M. Parkes, "Personal commentaries on 'ecosystems and human well-being: Health synthesis-a report of the millennium ecosystem assessment," EcoHealth, vol. 3, no. 3, pp. 136-140, 2006.

[37] Y. A. Izrael, S. M. Semenov, O. A. Anisimov et al., “The fourth assessment report of the intergovernmental panel on climate change: working group II contribution," Russian Meteorology and Hydrology, vol. 32, no. 9, pp. 551-556, 2007.

[38] O. E. Sala, F. S. Chapin III, J. J. Armesto et al., "Global biodiversity scenarios for the year 2100," Science, vol. 287, no. 5459, pp. 1770-1774, 2000.

[39] R. E. Green, S. J. Cornell, J. P. W. Scharlemann, and A. Balmford, "Farming and the fate of wild nature," Science, vol. 307, no. 5709, pp. 550-555, 2005.

[40] J. A. Foley, N. Ramankutty, K. A. Brauman et al., "Solutions for a cultivated planet," Nature, vol. 478, no. 7369, pp. 337-342, 2011.

[41] http://www.fao.org/fishery/topic/3541/en.

[42] B. Czech, P. R. Krausman, and P. K. Devers, "Economic associations among causes of species endangerment in the United States," BioScience, vol. 50, no. 7, pp. 593-601, 2000.

[43] M. L. McKinney, "Urbanization, biodiversity, and conservation," BioScience, vol. 52, no. 10, pp. 883-890, 2002.

[44] M. L. McKinney, "Measuring floristic homogenization by nonnative plants in North America," Global Ecology and Biogeography, vol. 13, no. 1, pp. 47-53, 2004.

[45] P. M. Vitousek, H. A. Mooney, J. Lubchenco, and J. M. Melillo, "Human domination of Earth's ecosystems," Science, vol. 277, no. 5325, pp. 494-499, 1997.

[46] R. I. Mcdonald, P. Kareiva, and R. T. T. Forman, "The implications of current and future urbanization for global protected areas and biodiversity conservation," Biological Conservation, vol. 141, no. 6, pp. 1695-1703, 2008.

[47] G. Buczkowski and D. S. Richmond, "The effect of urbanization on ant abundance and diversity: a temporal examination of factors affecting biodiversity," PLoS ONE, vol. 7, no. 8, 2012.

[48] P. Bolund and S. Hunhammar, "Ecosystem services in urban areas," Ecological Economics, vol. 29, no. 2, pp. 293-301, 1999.

[49] G. McGranahan, P. Marcotullio, X. Bai et al., "Urban systems," in Ecosystems and Human Well-Being: Current State and Trends, R. Hassan, R. Scholes, and N. Ash, Eds., Island Press, Washington, DC, USA, 2006.

[50] R. Forman, Urban Regions: Ecology and Planning Beyond the City, Cambridge University Press, New York, NY, USA, 2008.

[51] G. McGranahan and D. Satterthwaite, "Urban centers: an assessment of sustainability, Annual Review of Environment and Resources, vol. 28, pp. 243-274, 2003.

[52] P. Clergeau, J.-P. L. Savard, G. Mennechez, and G. Falardeau, "Bird abundance and diversity along an urban-rural gradient: a comparative study between two cities on different continents," Condor, vol. 100, no. 3, pp. 413-425, 1998.

[53] S. P. D. Riley, R. M. Sauvajot, T. K. Fuller et al., "Effects of urbanization and habitat fragmentation on bobcats and coyotes in southern California," Conservation Biology, vol. 17, no. 2, pp. 566-576, 2003.

[54] UNPD (United Nations Population Division), World Urbanization Prospects: The 2005 Revision, New York, NY, USA, 2005.

[55] Science for Environment Policy, DG Environment News Alert Servce, 24, 2010.
[56] W. Thuiller, S. Lavorel, M. B. Araújo, M. T. Sykes, and I. C. Prentice, "Climate change threats to plant diversity in Europe," Proceedings of the National Academy of Sciences of the United States of America, vol. 102, no. 23, pp. 8245-8250, 2005.

[57] J. Memmott, P. G. Craze, N. M. Waser, and M. V. Price, "Global warming and the disruption of plant-pollinator interactions," Ecology Letters, vol. 10, no. 8, pp. 710-717, 2007.

[58] S. Dubey and R. Shine, "Restricted dispersal and genetic diversity in populations of an endangered montane lizard (Eulamprus leuraensis, Scincidae)," Molecular Ecology, vol. 19, no. 5, pp. 886-897, 2010.

[59] T. J. Davies, G. F. Smith, D. U. Bellstedt et al., "Extinction risk and diversification are linked in a plant biodiversity hotspot," PLoS Biology, vol. 9, no. 5, Article ID e1000620, 2011.

[60] K. J. Feeley and M. R. Silman, "Land-use and climate change effects on population size and extinction risk of Andean plants," Global Change Biology, vol. 16, no. 12, pp. 3215-3222, 2010.

[61] B. S. P. Wang, P. J. Charest, and B. Downie, "Ex situ storage of seeds, pollen, and in vitro cultures of perennial woody plant species," FAO Forestry Paper, vol. 113, p. 83, 1993.

[62] L. Glowka, F. Burhene-Guilmann, H. Synge, J. A. McNeely, and L. Gündling, A Guide To the Convention on Biological Diversity (Environmental Policy and Law Paper No. 30), IUCN, Switzerland, 1994.

[63] United Nations Conference on Environment and Development (UNCED), Convention on Biological Diversity, Geneva, Switzerland, 1992.

[64] P. K. Pati, S. P. Rath, M. Sharma, A. Sood, and P. S. Ahuja, "In vitro propagation of rose-a review," Biotechnology Advances, vol. 24, no. 1, pp. 94-114, 2006.

[65] W. Grout and W. Brian, "Meristem-tip culture for propagation and virus elimination," in Methods in Molecular Biology, R. D. Hall, Ed., pp. 115-125, Plant Cell Culture Protocol, Humana Press, Totowa, NJ, USA, 1999.

[66] G. Faccioli, "Control of potato viruses using meristem and stem-cutting cultures, thermotherapy and chemotherapy," in Virus and Virus-Like Diseases of Potatoes and Production of Seed Potatoes, G. Loebenstein, H. P. Berger, A. A. Brunt, and G. R. Lawsan, Eds., pp. 365-390, Kluwer Academic Publisher, Dordrecht, The Netheralands, 2001.

[67] G. R. Rout, A. Mohapatra, and S. M. Jain, "Tissue culture of ornamental pot plant: a critical review on present scenario and future prospects," Biotechnology Advances, vol. 24, no. 6, pp. 531560, 2006.

[68] C. M. Miguel, Adventitious regeneration and genetic transformation of almond (Prunus dulcis Mill.) [Ph.D. thesis], Faculty of Sciences, University of Lisbon, Lisbon, Portugal, 1998.

[69] O. McMeans, R. M. Skirvin, A. Otterbacher, and G. Mitiku, "Assessment of tissue culture-derived 'Gala' and 'Royal Gala' apples (Malus $x$ domestica Borkh.) for somaclonal variation," Euphytica, vol. 103, no. 2, pp. 251-257, 1998.

[70] O. Monteuuis, F. C. Baurens, D. K. S. Gogh, M. Quimado, S. Doulbeau, and J. L. Verdeil, "DNA methylation in acacia mangium in vitro and ex-vitro buds, in relation to their withinshoot position, age and leaf morphology of the shoots," Silvae Genetica, vol. 58, no. 5-6, pp. 287-292, 2009.

[71] B. Renau-Morata, S. G. Nebauer, I. Arrillaga, and J. Segura, "Assessments of somaclonal variation in micropropagated shoots of Cedrus: consequences of axillary bud breaking," Tree Genetics and Genomes, vol. 1, no. 1, pp. 3-10, 2005. 
[72] V. Rani and S. N. Raina, "Genetic analysis of enhancedaxillary-branching-derived Eucalyptus tereticornis Smith and E. camaldulensis Dehn. plants," Plant Cell Reports, vol. 17, no. 3, pp. 236-242, 1998.

[73] F. Zhang, Y. Lv, H. Dong, and S. Guo, "Analysis of genetic stability through intersimple sequence repeats molecular markers in micropropagated plantlets of Anoectochilus formosanus Hayata, a medicinal plant," Biological and Pharmaceutical Bulletin, vol. 33, no. 3, pp. 384-388, 2010.

[74] P. Joshi and V. Dhawan, "Assessment of genetic fidelity of micropropagated Swertia chirayita plantlets by ISSR marker assay," Biologia Plantarum, vol. 51, no. 1, pp. 22-26, 2007.

[75] R. M. Devarumath, S. Nandy, V. Rani, S. Marimuthu, N. Muraleedharan, and S. N. Raina, "RAPD, ISSR and RFLP fingerprints as useful markers to evaluate genetic integrity of micropropagated plants of three diploid and triploid elite tea clones representing Camellia sinensis (China type) and C. assamica ssp. assamica (Assam-India type)," Plant Cell Reports, vol. 21, no. 2, pp. 166-173, 2002.

[76] M. K. Panda, S. Mohanty, E. Subudi, L. Acharya, and S. Nayak, "Assessment of genetic stability of micropropagated plants of Curcuma longa L. by cytophotometry and RAPD analyses," International Journal of Integrative Biology, vol. 1, no. 3, pp. 189195, 2007.

[77] W. Xing, M. Bao, H. Qin, and G. Ning, "Micropropagation of Rosa rugosa through axillary shoot proliferation," Acta Biologica Cracoviensia Series Botanica, vol. 52, no. 2, pp. 69-75, 2010.

[78] M. N. Nas, N. Mutlu, and P. E. Read, "Random amplified polymorphic DNA (RAPD) analysis of long-term cultured hybrid hazelnut," HortScience, vol. 39, no. 5, pp. 1079-1082, 2004.

[79] M. H. N. Mollel and E. M. A. Goyvaerts, "Micropropagation of marula, Sclerocarya birrea subsp. caffra (Anarcadiaceae) by axillary bud proliferation and random amplified polymorphic DNA (RAPD) analysis of plantlets," African Journal of Biotechnology, vol. 11, no. 93, pp. 16003-16012, 2012.

[80] C. Chen, J. Lan, S. Xie, S. Cui, and A. Li, "In vitro propagation and quality evaluation of long-term micro-propagated and conventionally grown Fagopyrum dibotrys Hara mutant, an important medicinal plant," Journal of Medicinal Plants Research, vol. 6, no. 15, pp. 3003-3012, 2012.

[81] S. Mohanty, R. K. Joshi, E. Subudi, S. Sahoo, and S. Nayak, "Genetic stability assessment of micropropagated mango Ginger (Curcuma amada Roxb.) through RAPD and ISSR markers," Research Journal of Medicinal Plant, vol. 6, no. 7, pp. 529-536, 2012.

[82] R. Parida, S. Mohanty, and S. Nayak, "Evaluation of genetic fidelity of in vitro propagated greater galangal (Alpinia galangal L.) using DNA based markers," International Journal of Plant, Animal and Environmental Sciences, vol. 1, no. 3, pp. 123-133, 2011.

[83] R. Gupta, M. Modgil, and S. K. Chakrabarti, "Assessment of genetic fidelity of micropropagated apple rootstock plants, EMLA 111, using RAPD markers," Indian Journal of Experimental Biology, vol. 47, no. 11, pp. 925-928, 2009.

[84] H. Pathak and V. Dhawan, "ISSR assay for ascertaining genetic fidelity of micropropagated plants of apple rootstock Merton 793," In Vitro Cellular and Developmental Biology, vol. 48, no. 1, pp. 137-143, 2012.

[85] H. Lata, S. Chandra, N. Techen, I. A. Khan, and M. A. Elsohly, "Assessment of the genetic stability of micropropagated plants of cannabis sativa by ISSR markers," Planta Medica, vol. 76, no. 1, pp. 97-100, 2010.

[86] E. L. Peredo, R. Arroyo-García, and M. Á. Revilla, "Epigenetic changes detected in micropropagated hop plants," Journal of Plant Physiology, vol. 166, no. 10, pp. 1101-1111, 2009.

[87] S. Gantait, N. Mandal, and P. K. Das, "Field evaluation of micropropagated vs. conventionally propagated elephant garlic," Journal of Agricultural Technology, vol. 7, no. 1, pp. 97-103, 2010.

[88] A. Kongbangkerd, A. Köpf, P. Allacher, C. Wawrosch, and B. Kopp, "Micropropagation of squill (Charybdis numidica) through nodule culture," Plant Cell Reports, vol. 23, no. 10-11, pp. 673-677, 2005.

[89] L. Annarita, "Morphological evaluation of olive plants propagated in vitro culture through axillary buds and somatic embryogenesis methods," African Journal of Plant Science, vol. 3, no. 3, pp. 037-043, 2009.

[90] S. Goto, R. C. Thakur, and K. Ishii, "Determination of genetic stability in long-term micropropagated shoots of Pinus thunbergii Parl. using RADP markers," Plant Cell Reports, vol. 18, no. 3-4, pp. 193-197, 1998.

[91] E. V. Soniya and M. R. Das, "In vitro micropropagation of Piper longum-an important medicinal plant," Plant Cell, Tissue and Organ Culture, vol. 70, no. 3, pp. 325-327, 2002.

[92] L. A. Caro, P. A. Polci, L. I. Lindström, C. V. Echenique, and L. F. Hernández, "Micropropagation of Prosopis chilensis (Mol.) Stuntz from young and mature plants," Biocell, vol. 26, no. 1, pp. 25-33, 2002.

[93] P. Bregitzer, S. Zhang, M.-J. Chob, and P. G. Lemaux, "Reduced somaclonal variation in barley is associated with culturing highly differentiated, meristematic tissues," Crop Science, vol. 42, no. 4, pp. 1303-1308, 2002.

[94] R. Medina, M. Faloci, M. A. Marassi, and L. A. Mroginski, "Genetic stability in rice micropropagation," Biocell, vol. 28, no. 1, pp. 13-20, 2004.

[95] M. Martins, D. Sarmento, and M. M. Oliveira, "Genetic stability of micropropagated almond plantlets, as assessed by RAPD and ISSR markers," Plant Cell Reports, vol. 23, no. 7, pp. 492-496, 2004.

[96] S. Dohling, S. Kumaria, and P. Tandon, "Multiple shoot induction from axillary bud cultures of the medicinal orchid, Dendrobium longicornu," AoB PLANTS, vol. 2012, 2012.

[97] R. K. Radha, A. M. Varghese, and S. Seeni, "Conservation through in vitro propagation and restoration of Mahonia leschenaultii, an endemic tree of the Western Ghats," ScienceAsia, vol. 39, pp. 219-229, 2013.

[98] H. S. Chawla, Introduction To Plant Biotechnology, Science press, 2nd edition, 2002.

[99] T. Murashige, "Plant propagation through tissue culture," Annual Review of Plant Physiology, vol. 25, pp. 135-166, 1974.

[100] C. Y. Hu and P. J. Wang, "Handbook of plant cell culture," in Meristem Shoot Tip and Bud Culture, D. A. Evans, W. R. Sharp, P. V. Ammirato, and Y. Yamada, Eds., pp. 177-227, Macmillan, New York, NY, USA, 1983.

[101] G. J. De Klerk, "How to measure somaclonal variation," Acta Botanica Neerlandica, vol. 39, pp. 129-144, 1990.

[102] S. K. Sharma, G. J. Bryan, M. O. Winfield, and S. Millam, "Stability of potato (Solanum tuberosum L.) plants regenerated via somatic embryos, axillary bud proliferated shoots, microtubers and true potato seeds: a comparative phenotypic, cytogenetic and molecular assessment," Planta, vol. 226, no. 6, pp. 1449 1458, 2007. 
[103] P. J. Larkin and W. R. Scowcroft, "Somaclonal variation—a novel source of variability from cell cultures for plant improvement," Theoretical and Applied Genetics, vol. 60, no. 4, pp. 197-214, 1981.

[104] A. R. Gould, "Factors controlling generations of variability in vitro," in Cell Culture and Somatic Cell Genetics in Plants. Plant Regeneration and Genetic Variability, I. K. Vasil, Ed., pp. 549567, Academic, Orlando, Fla, USA, 1986.

[105] S. M. Kaeppler, H. F. Kaeppler, and Y. Rhee, "Epigenetic aspects of somaclonal variation in plants," Plant Molecular Biology, vol. 43, no. 2-3, pp. 179-188, 2000.

[106] F. Ngezahayo, Y. Dong, and B. Liu, "Somaclonal variation at the nucleotide sequence level in rice (Oryza sativa L.) as revealed by RAPD and ISSR markers, and by pairwise sequence analysis," Journal of Applied Genetics, vol. 48, no. 4, pp. 329-336, 2007.

[107] H. Hirochika, K. Sugimoto, Y. Otsuki, H. Tsugawa, and M. Kanda, "Retrotransposons of rice involved in mutations induced by tissue culture," Proceedings of the National Academy of Sciences of the United States of America, vol. 93, no. 15, pp. 7783-7788, 1996.

[108] Z. L. Liu, F. P. Han, M. Tan et al., "Activation of a rice endogenous retrotransposon Tos 17 in tissue culture is accompanied by cytosine demethylation and causes heritable alteration in methylation pattern of flanking genomic regions," Theoretical and Applied Genetics, vol. 109, no. 1, pp. 200-209, 2004.

[109] F. Ngezahayo, C. Xu, H. Wang, L. Jiang, J. Pang, and B. Liu, "Tissue culture-induced transpositional activity of mPing is correlated with cytosine methylation in rice," BMC Plant Biology, vol. 9, article 91, 2009.

[110] X. Wang, R. Wu, X. Lin et al., "Tissue culture-induced genetic and epigenetic alterations in rice pure-lines, F1 hybrids and polyploids," BMC Plant Biology, vol. 13, p. 77, 2013.

[111] Y. R. Mehta and D. C. Angra, "Somaclonal variation for disease resistance in wheat and production of dihaploids through wheat x maize hybrids," Genetics and Molecular Biology, vol. 23, no. 3, pp. 617-622, 2000.

[112] S. Predieri, "Mutation induction and tissue culture in improving fruits," Plant Cell, Tissue and Organ Culture, vol. 64, no. 2-3, pp. 185-210, 2001.

[113] A. Karp, "Somaclonal variation as a tool for crop improvement," Euphytica, vol. 85, no. 1-3, pp. 295-302, 1995.

[114] E. Unai, T. Iselen, and E. de Garcia, "Comparison of characteristics of bananas (Musa sp.) from the somaclone CIEN BTA03 and its parental clone Williams," Fruit, vol. 59, pp. 257-263, 2004.

[115] T. J. Oh, M. A. Cullis, K. Kunert, I. Engelborghs, R. Swennen, and C. A. Cullis, "Genomic changes associated with somaclonal variation in banana (Musa spp.)," Physiologia Plantarum, vol. 129, no. 4, pp. 766-774, 2007.

[116] G. Grafi and Y. Avivi, "Stem cells: a lesson from dedifferentiation," Trends in Biotechnology, vol. 22, no. 8, pp. 388-389, 2004.

[117] G. Grafi, A. Florentin, V. Ransbotyn, and Y. Morgenstern, "The stem cell state in plant development and in response to stress," Frontiers in Plant Science, vol. 2, no. 53, pp. 1-10, 2011.

[118] B. McClintock, "The significance of responses of the genome to challenge," Science, vol. 226, no. 4676, pp. 792-801, 1984.

[119] M. R. Ahuja, "Somaclonal genetics of forest trees," in Somaclonal Variation and Induced Mutations in Crop Improvement, S. M. Jain, D. S. Brar, and B. S. Ahloowalia, Eds., pp. 105-121, Kluwer Academic, Dordrecht, The Netherlands, 1998.
[120] V. Rani and S. N. Raina, "Genetic fidelity of organized meristem-derived micropropagated plants: a critical reappraisal," In Vitro Cellular and Developmental Biology, vol. 36, no. 5, pp. 319-330, 2000.

[121] K. Gillis, J. Gielis, H. Peeters, E. Dhooghe, and J. Oprins, "Somatic embryogenesis from mature Bambusa balcooa Roxburgh as basis for mass production of elite forestry bamboos," Plant Cell, Tissue and Organ Culture, vol. 91, no. 2, pp. 115-123, 2007.

[122] R. Parra, M. T. Pastor, E. Pérez-Payá, and J. B. Amo-Marco, "Effect of in vitro shoot multiplication and somatic embryogenesis on 5-methylcytosine content in DNA of Myrtus communis L.," Plant Growth Regulation, vol. 33, no. 2, pp. 131-136, 2001.

[123] C. Diaz-Sala, M. Rey, A. Boronat, R. Besford, and R. Rodriguez, "Variations in the DNA methylation and polypeptide patterns of adult hazel (Corylus avellana L.) associated with sequential in vitro subcultures," Plant Cell Reports, vol. 15, no. 3-4, pp. 218221, 1995.

[124] X. Li, M. Xu, and S. S. Korban, "DNA methylation profiles differ between field- and in vitro-grown leaves of apple," Journal of Plant Physiology, vol. 159, no. 11, pp. 1229-1234, 2002.

[125] P. Smýkal, L. Valledor, R. Rodríguez, and M. Griga, "Assessment of genetic and epigenetic stability in long-term in vitro shoot culture of pea (Pisum sativum L.)," Plant Cell Reports, vol. 26, no. 11, pp. 1985-1998, 2007.

[126] M. Baránek, B. Křižan, E. Ondrušíková, and M. Pidra, "DNAmethylation changes in grapevine somaclones following in vitro culture and thermotherapy," Plant Cell, Tissue and Organ Culture, vol. 101, no. 1, pp. 11-22, 2010.

[127] S. Y. Park, H. N. Murthy, D. Chakrabarthy, and K. Y. Paek, "Detection of epigenetic variation in tissue-culture-derived plants of Doritaenopsis by methylation-sensitive amplification polymorphism (MSAP) analysis," In Vitro Cellular and Developmental Biology, vol. 45, no. 1, pp. 104-108, 2009.

[128] A. H. C. Wong, I. I. Gottesman, and A. Petronis, "Phenotypic differences in genetically identical organisms: the epigenetic perspective," Human Molecular Genetics, vol. 14, no. 1, pp. R11R18, 2005.

[129] E. A. Smith, S. B. Collette, T. A. Boynton et al., "Developmental contributions to phenotypic variation in functional leaf traits within quaking aspen clones," Tree Physiology, vol. 31, no. 1, pp. 68-77, 2011.

[130] S. Hirsch, R. Baumerger, and U. Grossniklaus, "Epigenetic variation,inheritance, and selection in plant populations," Cold Spring Harbor Symposia on Quantitative Biology, vol. 77, pp. 97104, 2012.

[131] M. A. Palombi and C. Damiano, "Comparison between RAPD and SSR molecular markers in detecting genetic variation in kiwifruit (Actinidia deliciosa A. Chev)," Plant Cell Reports, vol. 20, no. 11, pp. 1061-1066, 2002.

[132] J. A. Yoder, C. P. Walsh, and T. H. Bestor, "Cytosine methylation and the ecology of intragenomic parasites," Trends in Genetics, vol. 13, no. 8, pp. 335-340, 1997.

[133] R. A. Martienssen and V. Colot, "DNA methylation and epigenetic inheritance in plants and filamentous fungi," Science, vol. 293, no. 5532, pp. 1070-1074, 2001.

[134] R. I. S. Brettell and E. S. Dennis, "Reactivation of a silent Ac following tissue culture is associated with heritable alterations in its methylation pattern," Molecular and General Genetics, vol. 229, no. 3, pp. 365-372, 1991. 
[135] M. J. M. Smulders and G. J. de Klerk, "Epigenetics in plant tissue culture," Plant Growth Regulation, vol. 63, no. 2, pp. 137-146, 2011.

[136] M. Alizadeh and S. K. Singh, "Molecular assessment of clonal fidelity in micropropagated grape (Vitis spp.) rootstock genotypes using RAPD and ISSR markers," Iranian Journal of Biotechnology, vol. 7, no. 1, pp. 37-44, 2009.

[137] A. E. Mohamed, "Somaclonal variation in micropropagated strawberry detected at the molecular level," International Journal of Agricultural and Biological Engineering, vol. 9, no. 5, pp. 721-725, 2007.

[138] S. Saha, T. Dey, and P. Ghosh, "Micropropagation of Ocimum kilimandscharicum guerke (Labiatae)," Acta Biologica Cracoviensia Series Botanica, vol. 52, no. 2, pp. 50-58, 2010. 

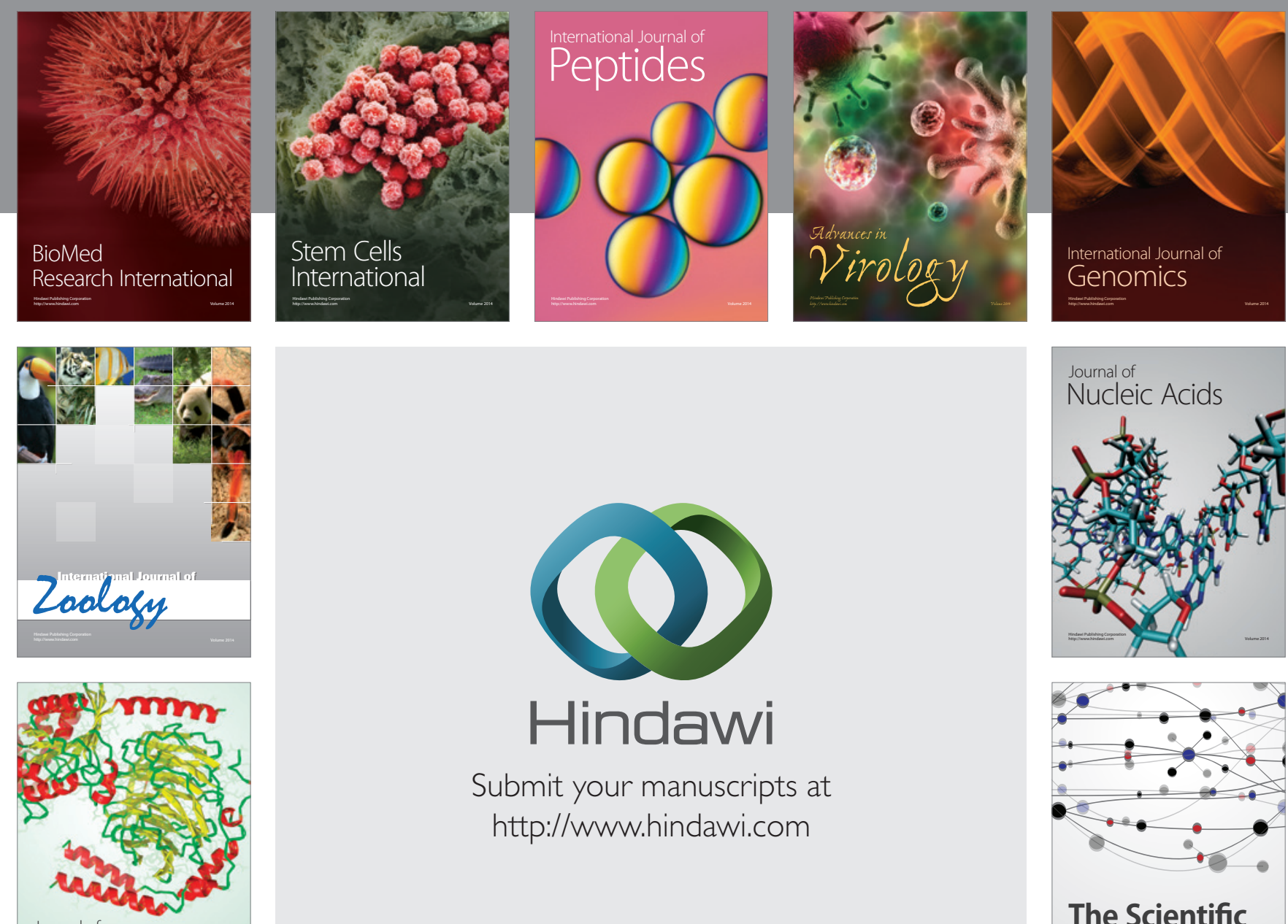

Submit your manuscripts at

http://www.hindawi.com

Journal of
Signal Transduction
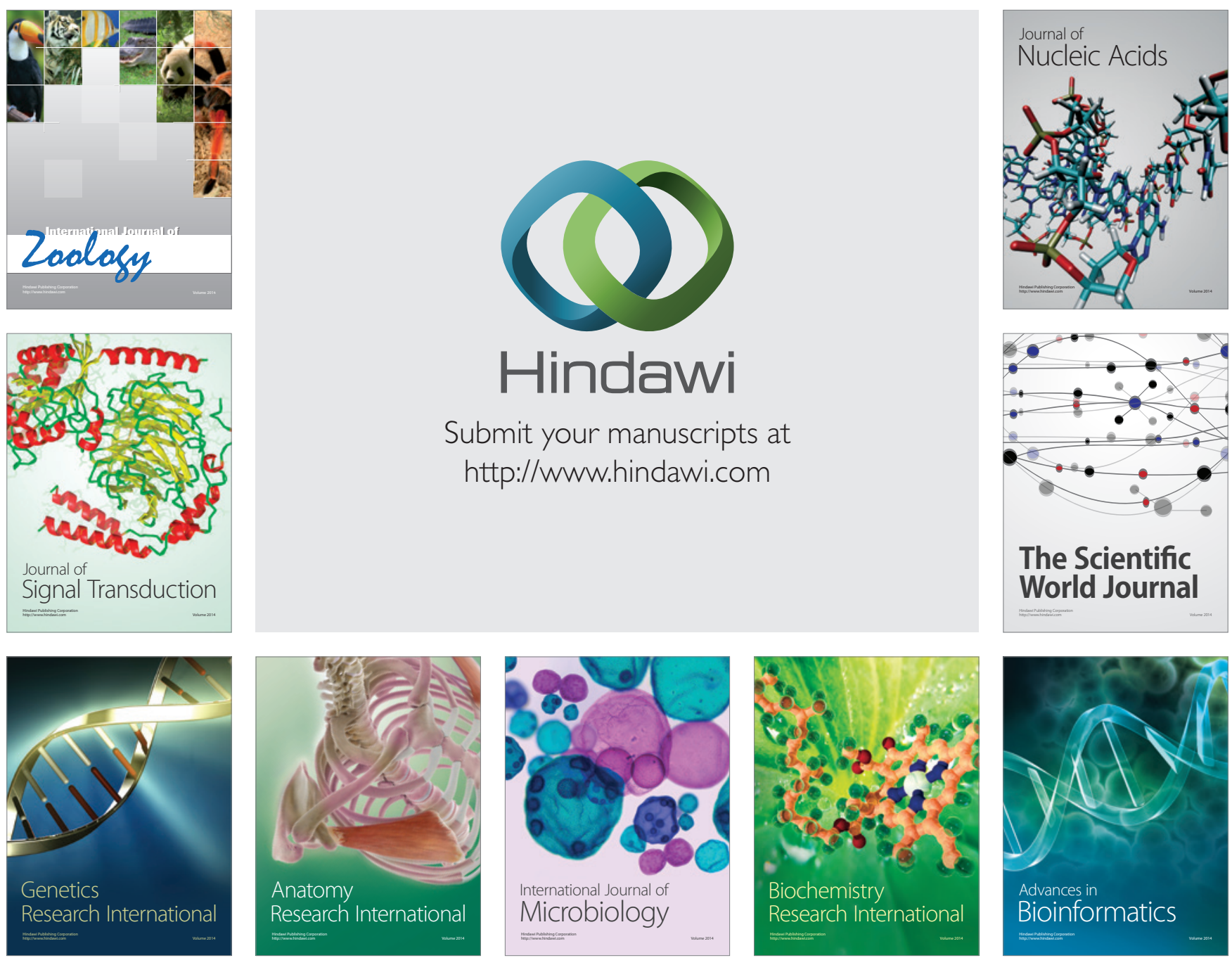

The Scientific World Journal
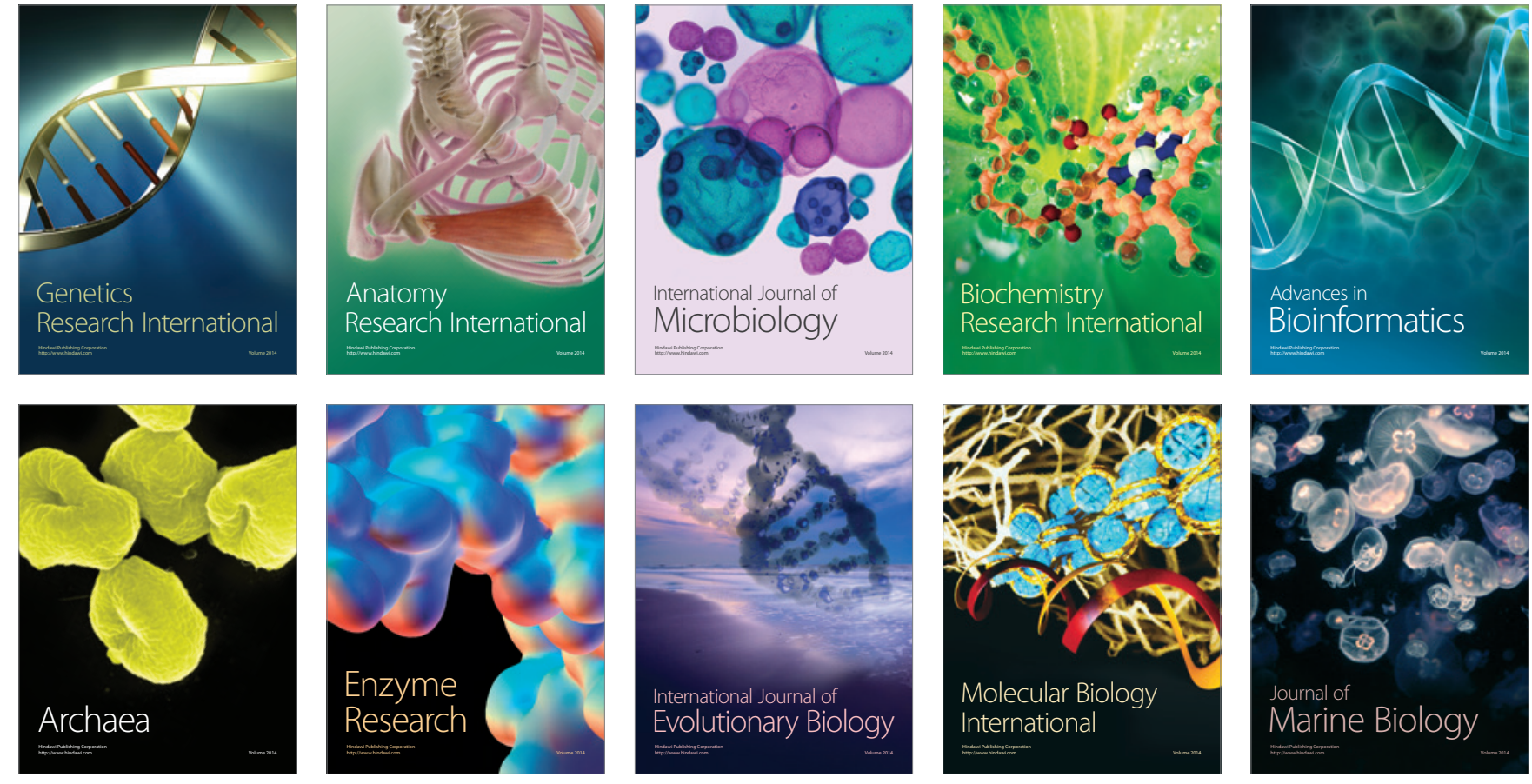